\title{
ZUHUD DALAM PERSPEKTIF SUNNAH
}

\author{
(Paradigma Neo-Sufisme)
}

\author{
Oleh: Firdaus ${ }^{1}$ \\ ${ }^{1}$ Institut Agama Islam Muhammadiyah Sinjai, \\ Jl. Sultan Hasanuddin, No. 20 Balangnipa, Sinjai \\ E-Mail: doktorfirdausgmail.com, Tlp.: +628114188997
}

\begin{abstract}
Abstrak
Sikap zuhud bukanlah sikap pesimistis terhadap kehidupan dunia dan tidak pula menganggapnya sebagai suatu hal yang harus tinggalkan. Akan tetapi Zuhud adalah suatu sikap mental yang mencerminkan pola hidup sederhana, tidak mementingkan kehidupan dunia secara berlebih-lebihan, namun tidak melupakannya sama sekali. Dunia bukanlah tujuan,te tapi tempat persinggahan dan tempat mengabdikan diri kepada Allah Swt. Zuhud tidak menolak, apalagi mengharamkan kekayaan. Zuhud hanya membenci kemewahan dan kehidupan dunia yang berlebih-lebihan. Seseorang boleh saja memiliki kekayaan yang melimpah, tetapi pola hidupnya tetap sederhana dan kekayaannya tersebut dipergunakan pada hal-hal yang dapat membuat dirinya lebih dicintai oleh Allah Swt dan lebih disenangi oleh orang lain. Sikap zuhud dan pola hidup sederhana telah dicontohkan oleh Rasulullah Saw dan para sahabatnya. Beliau dapat saja memiliki kekayaan, namun tidak dilakukannya. Selain itu, sikap zuhud akan melahirkan sifat-sifat terpuji, seperti qana'ah, tawadhu' dan syukur. Sifat-sifat ini dapat melahirkan ketenangan dalam kehidupan. Tidak lupa diri karena kekayaan yang melimpah di tangannya dan tidak sedih karena kemiskinan dan musibah yang menimpanya. Segala sesuatu yang terjadi pada dirinya selalu disandarkan pada Tuhan.
\end{abstract}

\section{Kata Kunci : Zuhud dan Sunnah}

\section{PENDAHULUAN}

$\mathrm{P}$ enafsiran kaum sufi terhadap makna zuhud dalam Islam terasa kurang menguntungkan karena sikapnya terhadap kehidupan dunia yang sangat pesimistis. Hal ini disebabkan oleh beberapa hal, yaitu pengaruh paham-paham yang didasarkan pada pandangan pesimistis terhadap dunia; latar belakang sejarah yang tidak menggembirakan dan faktor-faktor sosial lainnya yang menimpa ummat Islam selama lebih dari empat abad terakhir ini.

Pentingnya penghayatan spiritualitas dalam kehidupan modern yang materialistik tak bisa dipungkiri, lebih-lebih jika disadari bahwa dunia kemanusiaan saat ini makin sarat dengan kekerasan di bawah payung kapitalisme yang sekuler dan hedonistik.

Zuhud masih sering dianggap oleh sebagian orang "memiskinkan diri atau memandang hidup di dunia ini secara pesimistis. Padahal, jika dikaji lebih dalam, terutama sunnah yang menjelaskan tentang zuhud, maka akan didapati perspektif lain tentang zuhud, yang mungkin mengandung pesan moral seperti hidup sederhana, wajar, integratif, inklusif dan aktif dalam berbagai kehidupan, guna mengelola karunia Allah Swt. di dunia ini. 
Tokoh yang paling ideal dalam spiritualitas tidak lain adalah Muhammad, Rasulullah Saw. Makna spiritualitas yang telah dicontohkannya, yang kemudian diikuti oleh para sahabat pada masa awal, bukanlah jalan terbaik untuk membangun mahligai di langit, melainkan jalan yang turun dari kesadaran untuk memenangkan perjuangan di muka bumi ini.

Untuk mengetahui pandangan dan pengalaman zuhud Rasulullah lebih jauh, berikut ini akan dikemukakan hadis-hadisnya tentang zuhud. Agar pembahasan ini dapat lebih terfokus pada zuhud, maka berikut ini akan dikemukakan beberapa masalah, yaitu 1) Bagaimana hakikat zuhud menurut hadis-hadis Nabi. 2) Bagaimana kezuhudan Rasulullah Saw. 3) Apakah faedah yang ditimbulkan zuhud dapat mengatasi permasalahan manusia modern yang telah dicekoki oleh kehidupan materialisme dan kapitalisme, yang sering kali mengalami krisis spiritual.

\section{PEMBAHASAN}

\section{A. Pengertian Zuhud}

Secara etimologi, kata zuhud terdiri dari tiga huruf, yaitu za, ha dan dal, yang berarti "sedikitnya sesuatu". Sedangkan kata zahid berarti "sesuatu yang sedikit", seperti dikemukakan dalam suatu kalimat rajulun zāhid artinya seorang laki-laki yang makannya sedikit (Ahmad bin Fāris bin Zakariya, 1994: 462). Arti sedikit ini juga dapat dilihat dalam hadis yang diriwayatkan oleh imam al-Bukhārì (Imam al-Bukhārì, 2002: 85).

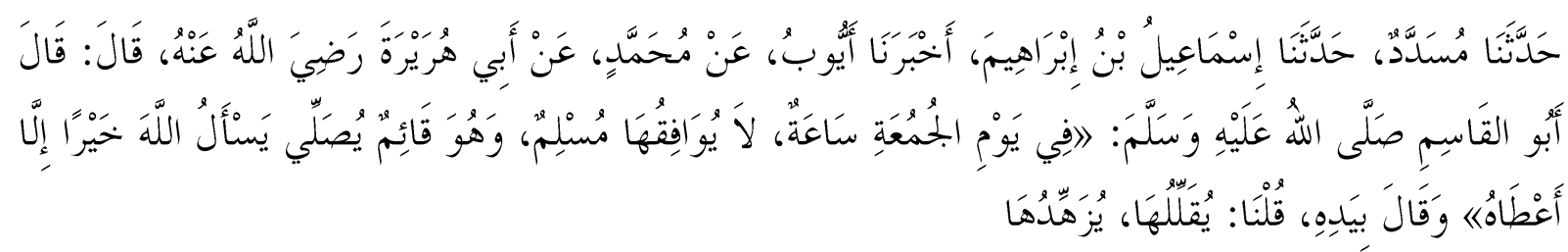

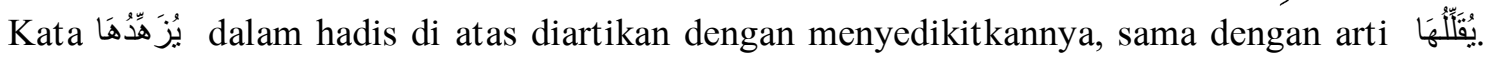
Selain itu, kata zuhud juga berarti raghaba 'an syay'i wa tarakah $\bar{u}$, artinya benci atau tidak tertarik terhadap sesuatu dan meninggalkannya, misalnya dikatakan zahada fi al-dunyā, artinya tidak tertarik dan menjauhkan diri dari kesenangan dunia untuk ibadah (Ahmad Warson Munawwir, 1984: 626). Orang yang mengamalkan zuhud disebut zāhid, zuhhād atau zāhidun. Zāhidah jamaknya zuhdan artinya kecil atau sedikit.

Di dalam al-Qur'an, kata yang seakar dengan zuhud hanya disebutkan satu kali, yaitu kata alzāhidīn pada QS. Yusuf/12: 20, berikut ini:

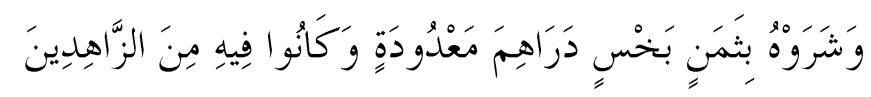

Terjemahnya:

"Dan mereka menjual Yusuf dengan harga yang murah, yaitu beberapa dirham saja, dan mereka merasa tidak tertarik hatinya kepada Yusuf". (Departemen Agama RI, 2012:

Kata zāhid dalam ayat di atas berarti ketidaktertarikan atau ketidakinginan para penjualnya kepada Yusuf karena mereka mendapati tanda-tanda kecerdasan, kemerdekaan dan akhlak yang 
tinggi pada dirinya. Mereka (kaum musafir yang menemukan Yusuf) tidak mau bertanggung jawab atas diri Yusuf, karena itu, mereka segera menjualnya kepada Raja Qifthir dan isterinya Zulaikha.

Selain itu, ada juga yang mengartikan zuhud dengan "ketakpedulian dan penghindaran". Ketakpedulian ini diarahkan pada dua hal, yaitu hal yang bersifat instinktif dan spiritual pengetahuan. Bersifat instinktif artinya tidak punya keinginan apapun terhadap sesuatu, seperti orang yang sakit enggan terhadap makanan, buah-buahan atau hal-hal yang dapat menyembuhkannya. Sedangkan ketakpedulian yang bersifat spiritual-pengetahuan dimaksudkan sebagai ketakpedulian terhadap materi yang tidak dianggap sebagai tujuan dan sasaran mencapai kebahagiaan. Materi atau duniawi hanyalah alat untuk menggapai tujuan yang paling tinggi, yaitu mengingat Allah Swt, cinta kepada-Nya dan keinginan untuk berada sedekat mungkin dengan-Nya (Murtadha Mutahhari, 2002: 148). Zuhud dalam arti ini sudah melampaui ketertarikan terhadap lingkup eksistensi material.

Adapun makna zuhud secara terminologi dapat dilihat dalan dua hal, yaitu zuhud sebagai bagian yang tak terpisahkan dari tasawuf dan zuhud sebagai akhlak Islam. Apabila tasawuf diartikan dengan adanya kesadaran dan komunikasi langsung antara manusia dengan Tuhan sebagai perwujudan ihsan, maka zuhud merupakan suatu maqam menuju tercapainya "perjumpaan" atau ma'rifat kepada-Nya (Harun Nasution, 1978: 56). Dalam arti ini, A. Mukti Ali-sebagaimana dikutip oleh Amin Syukur mengemukakan bahwa zuhud berarti menghindari keinginan terhadap hal-hal yang bersifat duniawi atau hal-hal lain selain daripada Allah Swt. (Amin Syukur, 1997: 1).

Zuhud merupakan suatu sikap yang berusaha menjauhkan diri dari kelezatan dunia dan mengingkarinya meskipun halal, dan menjalankan agama melebihi ketentuan yang telah ditetapkan oleh syariat. Semua ini dilakukan untuk meraih keuntungan akhirat dan menggapai ridha, bertemu dan ma'rifat Allah Swt. Bagi seorang sufi, makam zuhud merupakan langkah awal dalam rangka menempuh beberapa makam selanjutnya. Oleh sebab itu, zuhud dipandang sebagai landasan utama bagi seorang sufi dalam perjalanan spiritualnya mendekati hadirat ilahi.

Sedangkan zuhud sebagai akhlak Islam adalah sikap hidup yang memandang dunia ini sebagai sarana ibadah untuk mendapatkan keridhaan Allah Swt. dan bukan sebagai tujuan hidup. Dunia dipandang sebagai suatu yang fana. Cinta yang berlebih-lebihan terhadapnya akan melahirkan sifatsifat mazmümah (tercela). Sikap zuhud seperti ini telah dicontohkan oleh Nabi Saw dan para sahabatnya (Ibnu Khaldūn, t.th.: 370).

Sikap zuhud mampu melahirkan sifat tawādhu', tidak merasa bangga atas kemewahan dunia yang telah ada di tangan dan tidak merasa sedih hanya karena hilangnya kemewahan itu dari tangannya (QS. Al-Hadid/57: 3). Ia tetap bekerja dan berusaha, namun tidak pernah terlena dengan duniawi dan tidak pernah menguasai kecenderungan kalbunya apalagi ingkar kepada Tuhan. Dalam sebuah hadis, Rasulullah Saw menjelaskan sikap zuhud (Ibnu Mājah, 1998: 1373). 


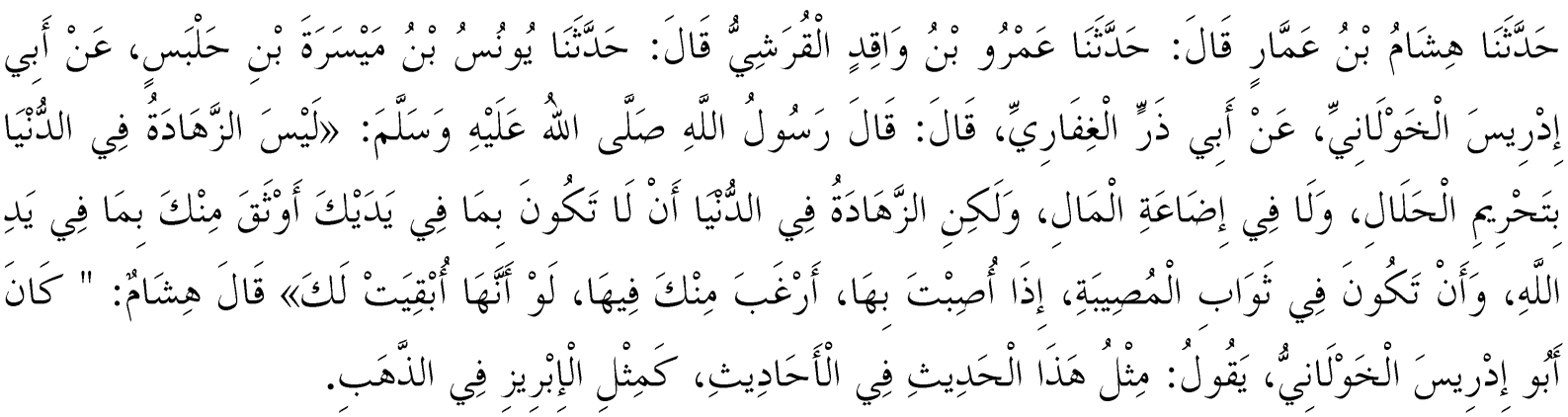

Artinya:

"Dari Abi Dzar al-Ghifārī berkata: Rasulullah Saw. bersabda: zuhud terhadap dunia bukanlah dengan mengharamkan yang halal dan bukan pula dengan menyia-nyiakan (mengabaikan) harta. Akan tetapi yang disebut zuhud terhadap dunia adalah tidak menjadikan apa yang ada di tanganmu (milikmu) lebih berat (kesenanganmu) daripada apa yang ada di tangan Allah Swt. Dan pahala dari musibah yang menimpamu lebih engkau senangi, meskipun sekiranya musibah itu dikekalkan bagimu".

\section{B. Zuhud dalam Hadis Nabi}

Hadis yang menjelaskan tentang zuhud banyak sekali, namun yang merujuk kepada lafaz zahada secara langsung beserta isytiqāq-nya (derivasinya) berjumlah 46 buah hadis saja (A.J.Wensinck, t.th.: 384-385). Di antara hadis-hadis tersebut banyak yang memiliki lafal dan makna yang sama. Karena itu, hadis yang memiliki lafal atau makna yang sama, tidak akan dikemukakan lagi.

\section{Hakikat Zuhud}

Zuhud adalah kondisi mental yang tidak ingin terpengaruh oleh harta dan kesenangan duniawi dalam mengabdikan diri kepada Allah Swt. Seperti yang telah dicontohkan oleh Nabi Sulaiman as. dan salah seorang sahabat Nabi Muhammad Saw. yaitu Usman bin Affan ra., yang betapapun kayanya, tetap hidup dalam keadaan zuhud. Mereka tidak terpengaruh oleh kekayaan itu dalam mengabdikan diri kepada Allah Swt. Zuhud seperti ini seiring dengan maksud firman Allah Swt. dalam QS. Al-Hadid/57: 23 berikut ini:

Terjemahnya:

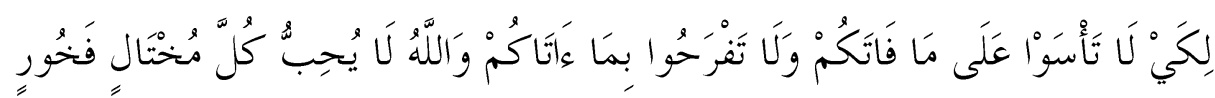

"(Kami jelaskan yang demikian itu) supaya kamu jangan berduka cita terhadap apa yang luput dari kamu, dan supaya kamu jangan terlalu gembira terhadap apa yang diberikan-Nya kepadamu. Dan Allah tidak menyukai setiap orang yang sombong lagi membanggakan diri”. Harta benda tidak dilarang untuk dimiliki, tetapi harta tersebut tidak boleh mempengaruhi atau memperbudak seseorang dalam mendekatkan diri kepada Allah Swt. Berikut ini akan dikemukakan beberapa hadis yang berhubungan dengan hakikat zuhud (Imam al-Tirmizī, 1998: 574).

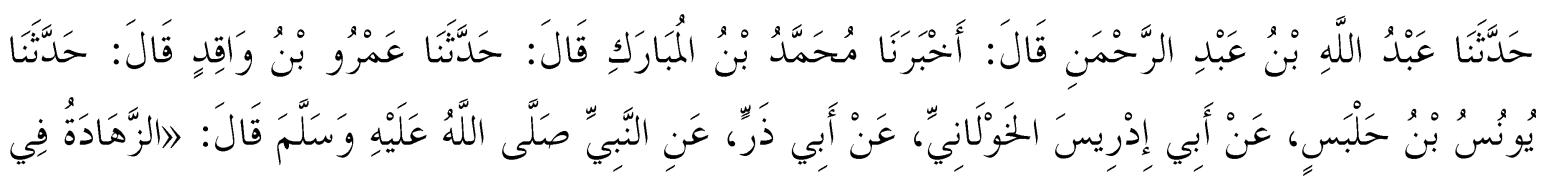




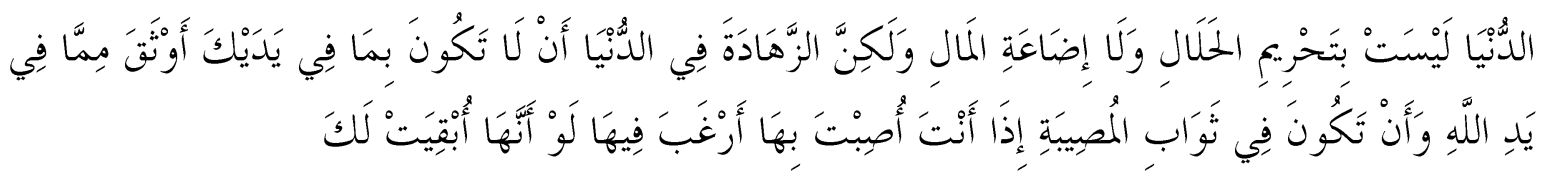

Artinya:

"Dari Abi Żar, dari Rasulillah Saw. bersabda: zuhud terhadap dunia bukanlah mengharamkan yang halal dan bukan pula menyia-nyiakan harta, tetapi zuhud terhadap dunia adalah tidak menjadikan apa yang ada di tanganmu (milikmu) lebih kamu percayai daripada apa yang ada di tangan (kekuasaan) Allah Swt. dan menjadikan musibah yang menimpa dirimu lebih engkau senangi meskipun musibah itu dikekalkan bagimu".

Berdasarkan hadis di atas, dapat dipahami bahwa pada hakikatnya zuhud bukanlah suatu sikap yang menolak dan meninggalkan kehidupan dunia apalagi sampai mengharamkannya. Hal ini juga didasarkan pada firman Allah Swt. yang mencela keras orang-orang yang menolak untuk menikmati karunia-Nya (QS. Al-A'rāf/7: 32).

Pada perspektif lain, hadis di atas dapat dipahami bahwa hakikat zuhud bukanlah menolak dan meninggalkan kehidupan dunia, juga tidak ambisius untuk memperoleh kemewahan dunia, seolah-olah kemewahan dunia di atas segala-galanya. Akan tetapi zuhud adalah menerima pemberian atau nikmat Allah Swt dengan sikap qanä'ah dan bersabar atas musibah yang ditimpakan kepadanya.

Di samping itu, zuhud bukan berarti menyia-nyiakan harta dan melarang mencari harta. Harta atau materi tetap dibutuhkan, namun ia hanyalah sebagai alat untuk lebih mendekatkan diri kepada Allah Swt. Yang dilarang adalah mencintai harta secara berlebih-lebihan sehingga ia diperbudak olehnya. Akibatnya, lupa dan semakin jauh dari Tuhan.

Kemudian dalam hadis itu juga, dapat dipahami bahwa hakikat zuhud adalah sikap mental atau keyakinan yang sangat besar terhadap kekuasaan Allah Swt., melebihi segala-galanya, meskipun sesuatu itu telah berada dalam genggamannya. Ini dapat dipahami dari penggalan hadis

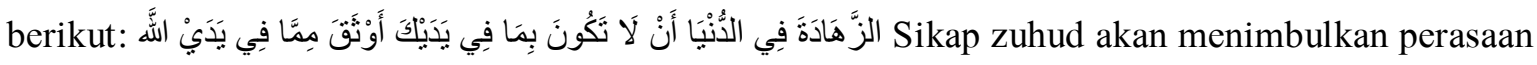
yang tenang dan selalu merasa senang, tidak pernah berkelu kesah terhadap segala macam cobaan hidup. Musibah yang menimpanya akan diterima dengan penuh kesabaran, ridha menerima segala ketentuan Tuhan. Dalam hadis yang lain yang diriwayatkan oleh Imam Muslim (Muslim, t.th.: 2052)

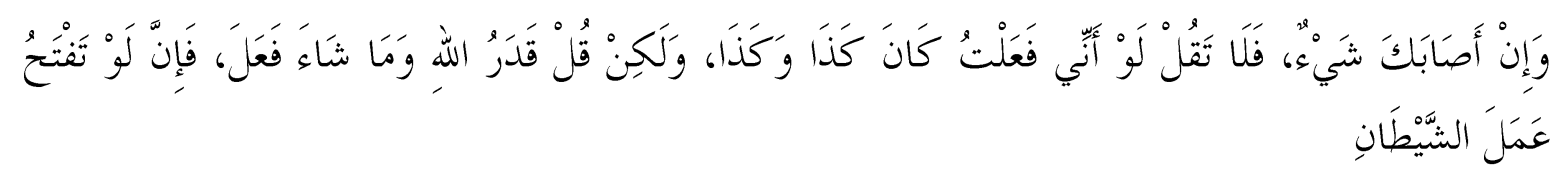

Artinya:

"Dan jika suatu musibah menimpamu, maka janganlah engkau mengatakan: sekiranya aku telah berbuat begini dan begitu, maka jadinya akan begini, melainkan hendaklah kamu mengatakan: Allah Swt. telah mentakdirkan apa yang Ia kehendaki, Ia perbuat,. Sesungguhnya perkataan: "Andaikata" membuka peluang masuknya syaitan".

\section{Zuhud Rasulullah Saw.}

Rasulullah Saw. adalah sosok manusia yang patut diteladani dalam segala aspek kehidupan. Kehidupan beliau sangat sederhana, meskipun beliau seorang kepala negara. Beliau memiliki 
kesempatan untuk menjadi orang yang kaya raya. Segala yang diinginkan dapat saja diraih, namun beliau tidak tertarik dengan kegemerlapan dunia. Beliau lebih memilih hidup sederhana.

Dalam suatu riwayat dikemukakan bahwa suatu ketika, Umar bin al-Khațāb masuk rumah Rasulullah Saw. dan mendapati beliau sedang tidur berbaring di atas sebuah tikar. Ketika beliau (Rasulullah Saw.) bangun, pada tubuhnya terlihat garis-garis merah bekas tikar tersebut. Dan ketika aku (Umar) melihat sekelilingnya (lemarinya), aku tidak mendapatkan sesuatu kecuali dua genggam gandum dan dua biji qarz kulit yang telah disamak. Aku tersentuh dan seketika itu aku menangis. Lalu Rasulullah bertanya: wahai Umar, apa gerangan yang membuat kamu menangis ? Umar menjawab: aku menangis karena melihat kesederhanaanmu, pada hal engkau adalah sebaikbaik manusia dan kekasih Allah Swt. Sementara Kaisar dan Kisra hidup dalam kemewahan. Hai Umar, kata Nabi: Tidak relakah engkau akhirat menjadi bagian kita sedangkan dunia bagian mereka. Kemudian Nabi menambahkan: Ber-tahmīd-lah kepada Allah Azza Wa Jalla (Al-Baihaqi, 1969: 247-248).

Tempat tinggal beliau adalah sebuah pondok kecil yang sederhana, beratap jerami, tiap kamar dipisah dengan batang pohon pelana (Fazlurrahman Anshari, 1983: 11). Di tempat sederhana itulah beliau tinggal bersama istri-istrinya. Peralatan rumahnyapun sangat sederhana, seperti tikarnya terbuat dari kulit dan rumput kering (Al-Baihaqi, t.th.: 155). Melihat kesederhanaan beliau, seorang wanita Anșar tersentuh hatinya dan kemudian dia pulang ke rumahnya mengambil alas yang terbuat dari bulu kambing untuk dihadiahkan kepada Rasulullah Saw. Ketika beliau (Rasulullah Saw.) datang dan melihatnya, beliau menyuruh Fatimah untuk mengembalikannya. Fatimah mengembalikannya setelah beliau memerintahkannya tiga kali (AlBaihaqi, t.th.: 147-248).

Dalam hal makanan, beliau pun sangat sederhana. Makannya hanya roti tawar dengan air putih. Beliau baru minum susu apabila diberi oleh tetangganya. Terkadang, perapiannya tidak pernah dinyalakan selama berbulan-bulan. Aisyah ra. menceritakan bahwa keluarga Nabi tidak pernah merasakan kenyang dari roti gandum selama tiga malam berturut-turut sampai beliau wafat (Al-Baihaqi, t.th.: 252-253).

Itulah gambaran kesederhanaan Rasulullah Saw. dalam kehidupannya. Beliau tidak pernah memikirkan kemegahan dan kemewahan dunia, meskipun beliau sangat mampu mendapatkannya, mengingat kekuasaan berada di tangannya, sehingga apapun yang diinginkannya dapat saja dimilikinya. Namun beliau lebih memilih hidup sederhana (zuhüd), hidup dalam keadaan fakir dan miskin.

\section{Tidak Mengabaikan Kehidupan Duniawi}

Imam Muslim meriwayatkan sebuah hadis mengenai hal ini (Muslim, t.th.: 2277). 


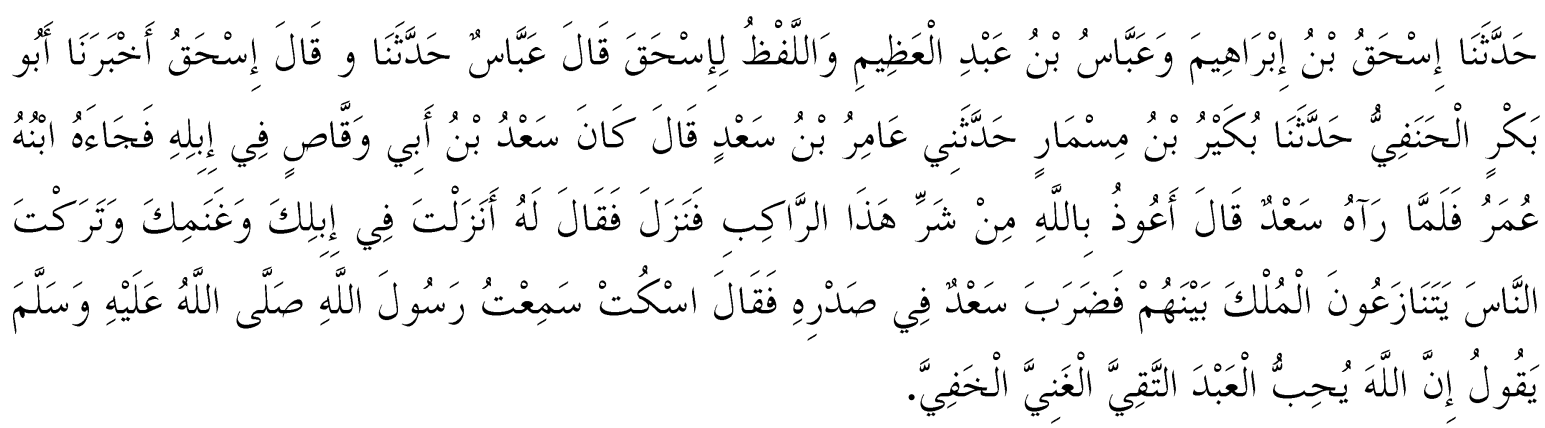

Artinya:

"Āmir bin Sa'ad berkata bahwa ketika Sa'ad bin Abi Waqqās berada di atas ontanya lalu anaknya 'Umar mendatanginya, maka tatkala Sa'ad melihatnya, ia berkata: aku berlindung kepada Allah dari kejelekan kendaraan (onta) ini, lalu ia turun dan 'Umar berkata kepadanya: apakah engkau telah berdiam pada onta dan piaraanmu (kambingmu) dan membiarkan manusia berebut kekuasaan diantara mereka, kemudian Sa'ad menepuk pundaknya dan berkata: Diamlah, aku telah mendengar Rasulullah Saw. bersabda: Sesungguhnya Allah Swt. mencintai hamba yang bertakwa yang kaya lagi rendah hati”.

Hadis di atas menjelaskan bahwa kekayaan bukanlah hal yang dibenci dan dilarang. Bahkan

kekayaan dapat lebih meningkatkan kemuliaan bagi seseorang, baik di mata Tuhan maupun di mata manusia, asalkan kekayaan itu dimanfaatkan sesuai dengan tuntunan syariat. Dalam riwayat lain dijelaskan bahwa mukmin yang kuat lebih baik dan lebih dicintai oleh Allah Swt. daripada mukmin yang lemah. Demikian hadis yang diriwayatkan oleh Imam Muslim (Muslim, t.th.: 2052).

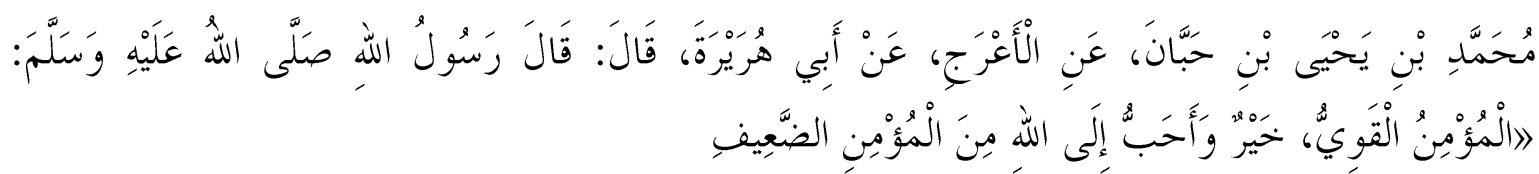

Kuat dalam hadis di atas tidak hanya terbatas pada kekuatan fisik, tapi juga kekuatan materi (kaya) dan ilmu.

Dengan demikan dapat dipahami bahwa mencari kekayaan bukan hal yang harus ditinggalkan, melainkan harus dicari dan diupayakan. Kaya bukan berarti mengabaikan kehidupan zuhud, begitu pula sebaliknya zuhud tidak berarti membenci kehidupan dunia. Dunia tetap diperhatikan, namun perhatian tersebut tidak sampai lupa kepada Tuhan, bahkan kehidupan dunia dijadikan alat untuk lebih mendekatkan diri kepada-Nya. Dalam kehidupan para Nabi pun terlihat betapa mereka tidak menyia-nyiakan kehidupan dunia. Mereka tetap mengenakan kain woll yang pada saat itu merupakan pakaian yang mewah, mengendarai himar dan tetap menyalurkan keinginan mereka. Hal ini digambarkan dalam riwayat berikut (Yūsuf bin Mūsā al-Hanafî̀ Abì alMahāsin, t.th.: 210).

$$
\begin{aligned}
& \text { عن الني صلى الله عليه وسلم البذاذة من الإيمان يعني التقشف من سيما أهل الإيمان لأن معهم الزهد } \\
& \text { و التواضع و كان الأنبياء يلبسون الصوف وير كبون الحمير ويحلبون الشاء }
\end{aligned}
$$

Islam mengajarkan agar manusia tidak diperbudak oleh harta benda dan kemegahan dunia yang bersifat semu dan artivisial. Harta benda tidak boleh mengendalikan pemiliknya, tapi pemiliknyalah yang mengendalikannya dan memanfaatkannya sesuai dengan perintah agama. Harta yang dimiliki harus diinfakkan kepada mereka yang berhak (membutuhkan) sesuai dengan 
petunjuk agama. Tidak boleh terlena dengan kesenangan dunia, sehingga dunia lebih utama baginya. Orang yang lebih mengutamakan dunia akan memperoleh cobaan dari Allah Swt. dalam bentuk kefakiran dan kerakusan. Hal ini dikemukakan di dalam riwayat berikut (Abū Shujā' Shirwaih, 1986: 68).

$$
\text { غناه وشغل سعيد ما سكن حب الدنيا قلب عبد إلا ابتلاه الله بخصال ثلاث بأمل لا يبلغ منتهاه وفقر لا يدرك }
$$

Kecintaan terhadap kehidupan dunia tidak boleh berlebih-lebihan, namun tidak boleh juga dilupakan apalagi ditinggalkan. Zuhud mengajarkan keseimbangan antara kehidupan duniawi dan ukhrawi (QS. Al-Qasas/28: 77). Keduanya harus dipandang sebagai suatu kesatuan yang integral dan tidak dapat dipisahkan, apalagi dengan mengisolasi diri dari kehidupan sosial kemasyarakatan. Dalam suatu riwayat dikemukakan sebagai berikut (Al-Hāris bin abī Usāmah, 1992: 983).

$$
\begin{aligned}
& \text { حدثنا أبو عبد الرحمن المقرىء ثنا أبو عمرو الصفار عن عبد الله بن العيزار قال لقيت شيخا بالرمل من } \\
& \text { الأعراب كبيرا فقلت له لقيت أحدا من أصحاب رسول الله صلى الله عليه وسلم قال نعم فقلت من فقال } \\
& \text { عبد الله بن عمرو بن العاص فقلت له فما سمعته يقول قال سمعته يقول ثم احرز لدنياك كأنك تعيش أبدا } \\
& \text { واعمل لآخر تك كأنك تموت غدا }
\end{aligned}
$$

Artinya:

"Jagalah (perhatikanlah) duniamu seakan-akan engkau akan hidup selama-lamanya dan bekerjalah untuk akhiratmu seakan-akan engkau akan mati selama-lamanya”.

\section{Keutamaan Zuhud}

Di dalam sebuah hadis, Ibnu Mājah menguraikan keutamaan zuhud sebagaimana berikut (Ibnu Mājah, 1996: 1373).

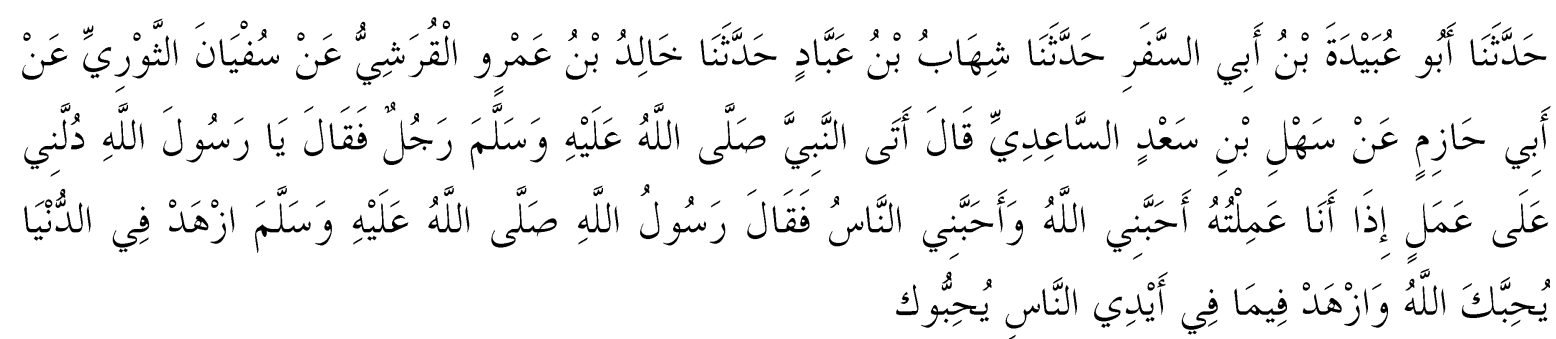

Artinya:

"Dari Sahl bin Sa'ad al-Sā'idi berkata: seorang laki-laki mendatangi Nabi Saw. lalu berkata: Ya Rasulullah Saw. tunjukkan kepadaku suatu perbuatan yang jika aku lakukan, Allah Swt. dan manusia akan mencintaiku. Rasulullah Saw menjawab: zuhud-lah terhadap kehidupan dunia, niscaya Allah Swt. akan mencintaimu dan zuhud pulalah terhadap apa yang dimiliki oleh orang lain, niscaya manusia akan mencintaimu".

Hadis di atas mengandung dua pesan Nabi yang penting, yaitu bersikap zuhud terhadap kehidupan dunia dan bersikap zuhud terhadap apa yang dimiliki oleh orang lain. Dengan kedua sikap zuhud tersebut, seseorang dapat meraih cinta Allah Swt. dan cinta manusia. 
Zuhud terhadap kehidupan dunia akan menjauhkan diri dari kecintaan yang berlebih-lebihan terhadap harta kekayaan. Cinta yang berlebih-lebihan terhadapnya akan menjadikan seseorang mudah diperbudak oleh harta. Sedangkan orang yang telah diperbudak oleh harta mudah lupa kepada Tuhan dan mengabaikan aturan-aturan-Nya. Dunia di atas segala-galanya dan menjadikannya sebagai tempat tujuan, sehingga dunia adalah surga baginya. Adanya sikap zuhud, membuat seseorang meyakini bahwa kehidupan dunia hanyalah bersifat semu dan tempat persinggahan belaka, bahkan menganggapnya penjara baginya. Hal ini sejalan dengan riwayat berikut (Muslim, t.th.: 2272).

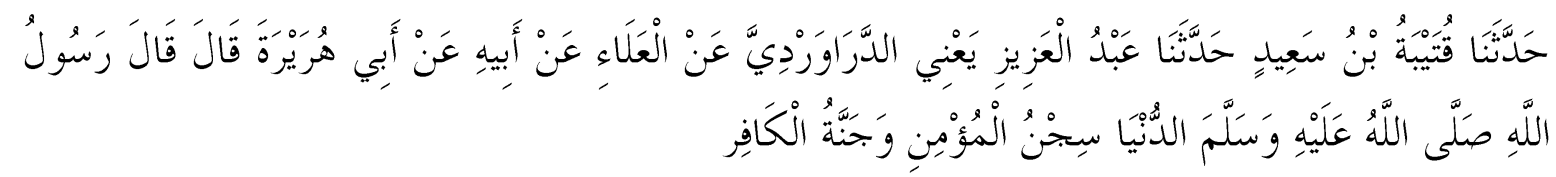

Sedangkan sikap zuhud terhadap apa yang dimiliki oleh orang lain akan melahirkan sikap qanä'ah, tawādhu', syūkur, dan lebih mendahulukan kepentingan orang lain di atas kepentingan diri sendiri. Sikap ini akan menjauhkan dirinya dari sifat-sifat seperti iri, dengki, takabur dan angkuh. Tidak adanya sifat-sifat buruk ini pada diri seseorang menyebabkan orang lain cinta kepadanya. Bahkan seorang zāhid akan mendatangkan atau memberikan hikmah bagi orang lain. Hal ini dikemukakan dalam hadis berikut ini (Ibnu Mājah, 1998: 1373).

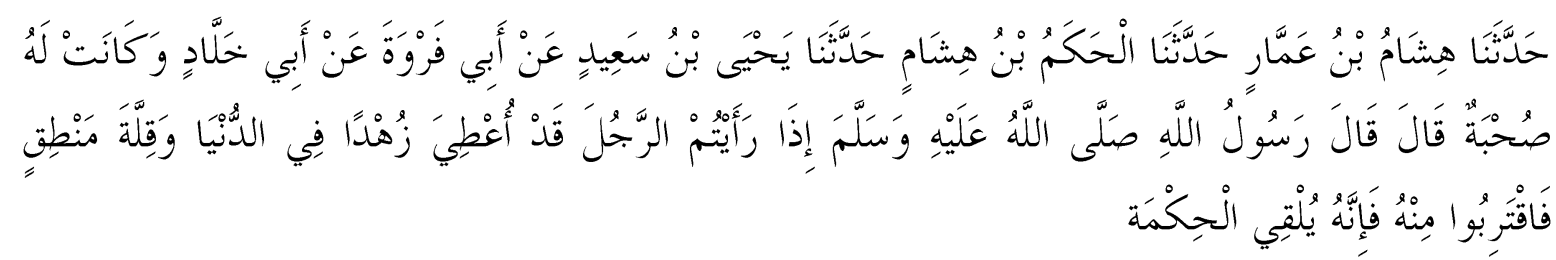

Artinya:

"Dari Abī Khālid dan dia bersama temannya berkata: Rasulullah Saw. pernah bersabda: Jika kamu seseorang yang telah diberi sifat zuhud terhadap kehidupan dunia dan sedikit bicara, maka dekatilah karena sesungguhnya ia diberikan hikmah".

Hadis di atas menjelaskan bahwa orang yang memiliki sifat zuhud akan diberikan hikmah.

Hikmah terambil dari kata ḩakama yang pada mulanya berarti menghalangi. Dari akar kata yang sama dibentuklah kata yang bermakna kendali, yakni sesuatu yang fungsinya mengantar kepada yang baik dan menghindarkan dari yang buruk. Untuk mencapai maksud tersebut diperlukan pengetahuan dan kemampuan menerapkannya. Dari sinilah hikmah dipahami dalam arti pengetahuan tentang baik dan buruk serta kemampuan menerapkan yang baik dan menghindar dari yang buruk (M. Quraish Shihab, 2000: 542). Maksud hikmah dalam hadis tersebut adalah banyak kebajikan. Hal ini sejalan dengan QS. Al-Baqarah/2: 269 berikut:

Terjemahnya:

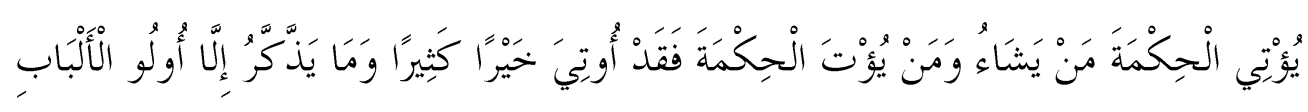

"Allah menganugrahkan al hikmah (kefahaman yang dalam tentang Al Qur'an dan As Sunnah) kepada siapa yang Dia kehendaki. Dan barangsiapa yang dianugrahi al hikmah itu, ia benar-benar telah dianugrahi karunia yang banyak. Dan hanya orang-orang yang berakallah yang dapat mengambil pelajaran (dari firman Allah)". 
Seorang zāhid yang telah memiliki pola hidup sederhana, tidak pernah merasa gelisah hanya karena kekurangan. Dalam sebuah riwayat yang dikemukakan oleh Ibnu Majah dijelaskan bahwa seorang zāhid selalu merasa senang, baik ia diberi ataupun tidak (Ibnu Mājah, 1998: 1385).

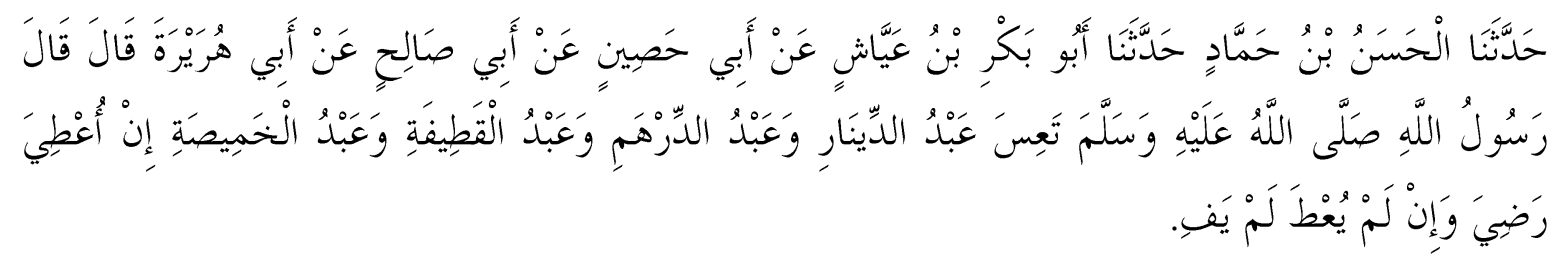

Hatinya selalu merasakan ketenangan dan kedamaian, rela terhadap segala keadaan. Segala sesuatunya selalu disandarkan kepada Allah Swt. Hatinya hanya merindukan Tuhan dan selalu merasakan akan kehadiran-Nya. Keinginannya hanya selalu ingin berjumpa dengan-Nya.

\section{KESIMPULAN}

Berdasarkan uraian di atas, ada beberapa kesimpulan yang dapat dikemukakan sebagai berikut:

1. Zuhud adalah suatu sikap mental yang mencerminkan sikap hidup sederhana, tidak mementingkan kehidupan dunia, namun tidak melupakannya sama sekali. Dunia bukanlah tujuan, tapi tempat persinggahan dan tempat mengabdikan diri kepada Allah Swt. Zuhud tidak menolak, apalagi mengharamkan kekayaan. Zuhud hanya membenci kemewahan dan kehidupan dunia yang berlebih-lebihan. Seseorang boleh saja memiliki kekayaan yang banyak, tetapi pola hidupnya tetap sederhana dan kekayaannya tersebut tidak membuatnya jauh dari Tuhan, tapi malah kekayaannya dipergunakan dan dimanfaatkan sesuai dengan tuntunan syariat, sehingga ia lebih dekat kepada Allah Swt. Kekayaannya dipergunakan pada hal-hal yang dapat membuat dirinya lebih dicintai oleh Allah Swt. dan lebih senangi oleh orang lain.

2. Rasulullah Saw. bukan hanya sebagai Nabi, melainkan beliau juga sebagai kepala negara. Sebagai kepala negara, kekuasaan berada di tangannya, sehingga apapun yang diinginkannya, baik harta ataupun lainnya dapat saja dimiliki. Namun kekuasaannya tidak dipergunakan untuk memiliki kekayaan ataupun kemewahan hidup. Beliau hidup sederhana, bahkan hidup dalam keadaan miskin. Sandang dan pangan yang dimilikinya hanya penyambung hidup dan alat untuk mengabdi kepada Allah Swt.

3. Adanya sikap zuhud dalam diri seseorang, dapat melahirkan sifat-sifat mahmudah dalam dirinya, seperti tawādhu', qanā'ah, sabar dan pandai bersyukur. Ia selalu rela dalam berbagai keadaan, tidak gelisah karena musibah menimpanya dan tidak sombong karena kekayaan yang dimilikinya. Hatinya selalu bergantung kepada Tuhan, Allah Swt. selalu dalam ingatannya, ibadah kepada-Nya tidak pernah surut dan terganggu hanya karena duniawi semata.

\section{DAFTAR PUSTAKA}

Abī al-Mahāsin, Yūsuf bin Mūsa al-Hanafî. (t.th.). Mu'tasar al-Mukhtasar. Beirut: Maktabah alMutanabbì. 
Abī Usāmah, Al-Hāris. (1992). Musnad al-Hāriš. Madinah al-Munawwarah: Markaz Khidmah alSunnah wa al-Sirah al-Nabawiyah.

Al-Baihaqii. (1969). Dalā'il al-Nubuwwah. Madinah: Dār al-Kutub.

Al-Bukhārì, Muhammad ibn Ismā'ìl Abū 'Abdilāh al-Ju'fî. (2002). Sahịh al-Bukhārìi. Beirut: Dār Thaūq al-Najāh.

Anshari, Fazlur Rahman. (1983). Konsepsi Masyarakat Islam Moderen. Bandung: Risalah.

Ibnu Khaldūn. (t.th.). Al-Muqaddimah. ttp: Dār al-Fikr Li al-Tibā wa al-Nashr.

Ibnu Zakariyyā, Ahmad bin Fāris. (1994). Mu'jam Maqāyīis fì al-Lughah. Beirut: Dār al-Fikr.

Munawwir, Ahmad Warson. (1984). Al-Munawwir: Kamus Arab Indonesia. Yogyakarta: PP. alMunawwir.

Mutahhari, Murtada. (2002). Glimpses of the Nahj al-Baläghah. Jakarta: Islamic Center Jakarta.

Nasution, Harun. (1978). Filsafat dan Mistisisme dalam Islam. Jakarta: Bulan Bintang.

Al-Naisabūrì, Muslim ibn al-Hajjāj Abū al-Ḥasan al-Qushairì. (t.th.). Sahịḥ Muslim. Beirut: Dār Ihyā', al-Turāis al-Arabìy.

Al-Qazwīnī, Abū Abdillāh Muhammad ibn Yazìd. (1998). Sunan Ibnu Mājah. Beirut: Dār Ihyāà alKutub al-Arabiyyah.

Rahman, Fazlur. (2000). Islam. Bandung: Pustaka.

Shihab, M. Quraish. (2000). Tafsir al-Mishbah: Pesan, Kesan dan Keserasian al-Qur'an. Ciputat: Lentera Hati.

Shirwaih, Abū Shujā'. (1986). Al-Firdaus bi al-Ma'sūr al-Khịtāb. Beirut: Dār al-Kutub al-Ilmiyyah.

Syukur, Amin. (1997). Zuhud di Abad Moderen. Yogyakarta: Pustaka Pelajar.

Al-Tirmiżì, Muhammad ibn Isā ibn Saurah ibn Mūsā ibn Ḍahhāk. (1998). Sunan al-Tirmiží. Beirut: Dār al-Gharb al-Islāmìy.

Wensinck, A.J. K. (t.th.). Al-Mu'jam al-Mufahras li Alfăz al-Ahạd dïs al-Nabaw̄i. 